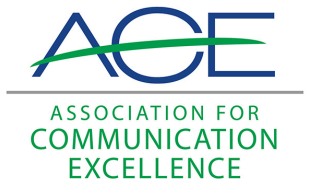

Journal of Applied Communications

\title{
American Ways: A Guide for Foreigners in the United States and The 10 Lenses: Your Guide to Living and Working in a Multicultural World
}

Pat Melgares

Follow this and additional works at: https://newprairiepress.org/jac

(c) (†)

This work is licensed under a Creative Commons Attribution-Noncommercial-Share Alike 4.0 License.

\section{Recommended Citation}

Melgares, Pat (2006) "American Ways: A Guide for Foreigners in the United States and The 10 Lenses: Your Guide to Living and Working in a Multicultural World," Journal of Applied Communications: Vol. 90: Iss. 4. https://doi.org/10.4148/1051-0834.1267

This Review is brought to you for free and open access by New Prairie Press. It has been accepted for inclusion in Journal of Applied Communications by an authorized administrator of New Prairie Press. For more information, please contact cads@k-state.edu. 


\title{
American Ways: A Guide for Foreigners in the United States and The 10 Lenses: Your Guide to Living and Working in a Multicultural World
}

\author{
Abstract \\ Two book reviews: American Ways: A Guide for Foreigners in the United States, by Gary Althen with \\ Amanda R. Doran and Susan J. Szmania; and The 10 Lenses: Your Guide to Living and Working in a \\ Multicultural World, by Mark A. Williams.
}




\section{American Ways: A Guide for Foreigners in the United States and The 10 Lenses: Your Guide to Living and Working in a Multicultural World}

American Ways: A Guide for Foreigners in the United States

Gary Althen with Amanda R. Doran and Susan J. Szmania

(Intercultural Press, London, 2003. 295 pages.

\$26.95, hardcover, ISBN-13: 978-1877864995; ISBN-10: 1877864994.)

The 10 Lenses: Your Guide to Living and Working in a Multicultural World

Mark A. Williams

(Capital Books, Herndon, VA, 2001. 160 pages.

\$24.95, hardcover, ISBN-13: 978-1892123756; ISBN-10: 1892123754.)

For many good reasons, a number of ACE members are thinking harder about the question of diversity.

At Kansas State University, we recently formed a diversity task force to encourage a greater understanding of diversity in our state and to provide more opportunities for experience and interaction with diverse groups.

Many of us face the same challenges: growing ethnic populations (particularly Spanish-speaking populations), limited human and financial resources to serve emerging groups, programming that does not adequately address specific minority audiences, and few opportunities to build our understanding of diverse audiences.

But that last piece-understanding diverse audiences-is not limited by budgets, human resources, or committee work.

In this review, I'll discuss two books that provide some useful background to help readers understand diversity in our society.

American Ways: A Guide for Foreigners in the United States is just under 300 pages, but you wouldn't know it. It's an easy read, set in about 12-point type, with fairly short chapters. Even if you read slowly, it's not tough to knock off 40 to 50 pages a night.

While the title might seem to indicate that the book is for people coming to the United States, you'll quickly find it can be quite the opposite. Whether this was intentional or not (I suspect it was), author Gary Althen cleverly outlines American life in ways that will make American readers stop and think. 


\section{Review}

That is, as an American, you'll find yourself asking: "Is that how we really act?"

Althen addresses many aspects of American life, including customs, cultural values, politics, education, religion, male/female relationships, sports and recreation, driving, shopping, behavior in public places, business, and nonverbal communication.

For instance:

- Residents of other countries often wonder why U.S. citizens are called "Americans." Technically, the Americas include Canada and the countries of Central and South America. Americans also would never see themselves as being "foreigners," even when visiting another country. We apply that term liberally to those from other countries, but are confused why those same people would call us "foreigners."

- In the U.S., people schedule meetings with the expectation that all parties to a discussion will get together at a given place and a given time. In some countries, showing up to a meeting is optional; a foreign visitor may show up or not, or may show up more than "fashionably late." If a foreign visitor misses a meeting, it may not be customary that they give a reason for doing so.

- In the U.S., heated public discussion about politics is taboo. Residents of other countries, however, enjoy heated discussion about politics, almost considering it a form of recreation. While Americans often become uncomfortable when discussing politics, foreigners may use this kind of discussion as an opportunity to get to know a person better.

- Americans raise their children to be freethinkers, believing that independent children will become responsible young adults who can provide for themselves away from the parents' home. Parents in other countries often shelter their children more closely, and are unfamiliar with American concepts such as daycare (while parents work), or "parents' night out" away from children. Also, when Americans use the word "family," they are often referring to the nuclear family. In other countries, "family" also includes aunts, uncles, grandparents, and others.

Many more differences exist in daily life. The basic premise for Americans is that a better understanding of our ways, and how foreigners' lifestyles or views differ, can make us more successful in relationships with visitors from other countries or with people from different backgrounds. 


\section{Review}

The last paragraph of the book is thought-provoking. Althen writes:

If you make the effort to understand Americans, you will begin to see how various aspects of American culture fit together. The patterns that underlie people's behavior will become more visible, and you will become increasingly able to predict what other people will do. Your interpretations will become more accurate, and you will be more willing to delay judgment. All this helps you to interact more constructively with Americans and to achieve your purposes in visiting the United States. (pp. 286-287)

A challenge: Re-read that paragraph, and substitute any nationality or ethnic group for the word "Americans" (for example, Hispanics). By doing so, you'll get the essence of the value in Althen's American Ways.

The second book, The 10 Lenses: Your Guide to Living and Working in a Multicultural World, is another easy read. It's about 220 pages, but it's really more of a reference book listing the 10 ways in which people generally view the world around them.

The 10 "lenses" outlined by author Mark Williams are described in the first 30 pages, and the rest of the book consists of in-depth descriptions, examples, case studies, and more about each of the viewpoints.

Williams' 10 lenses are provided below with brief descriptions:

1) Assimilationists, who want people to submerge their individual and cultural identities in favor of nationalistic and patriotic ideals.

2) The color-blind, who see people as individuals and ignore race, color, ethnicity, and other external cultural factors.

3) Culturalcentrists, who seek to improve the welfare of their cultural group by accentuating their history and identity.

4) Elitists, who believe in the superiority of the upper class and embrace the importance of family roots, wealth, and social status.

5) Integrationists, who support breaking down all barriers between social groups by merging people of different cultures together in communities and in the workplace.

6) Meritocratists, who believe in the individual credo of the United States: If you have the abilities and work hard enough, you can compete with anyone to make your dreams come true.

7) Multiculturalists, who celebrate the diversity of cultures in the United States and the contributions they make to our national character and history. 


\section{Review}

8) Seclusionists, who feel strongly that they should protect themselves from racial, cultural, and / or ethnic groups that diminish the character and quality of their group's experiences within the society.

9) Transcendents, or people who focus on the human spirit, our universal connection, and our shared humanity.

10) Victims/Caretakers, who see their liberation as a crucial goal. Victims/caretakers feel that they are still suffering from the generational impact of previous oppression. Therefore, they continue to deserve compensation from society and the dominant culture.

You may see yourself in more than one of these lenses; that is to be expected. But the strength with which each of us relates to any given lens will depend on our individual views of diversity.

Williams also suggests an $11^{\text {th }}$ lens: essentially, it is a blending of the 10 lenses. From this point of view, in order for there to be harmony in the world, each person's viewpoint and contributions must be valued, while a society that excludes or destroys any of the parts that make up the whole can only be destructive. When he presents his work publicly, Williams sings a song titled One Song, Many Voices to help explain the concept of an $11^{\text {th }}$ lens.

Gallup Research Labs (at the University of Nebraska-Lincoln) and The Diversity Channel have developed an instrument to more completely study an individual's or a group's diversity preference indicators.

At Kansas State University, we plan to use 10 Lenses in our work with the diversity task force. In the book, each of the 10 lens sections includes a three-question test to help readers determine how strongly they relate to that particular viewpoint. The questions will provide a good basis for an upcoming survey that will help us characterize our organization's collective views of multiculturalism.

\section{About the Reviewer}

Pat Melgares is marketing coordinator in the Department of Communications at Kansas State University. 
